\title{
AN ANAL YSIS OF USING ENGLISH IN CLASSROOM INTERACTION (A STUDY AT THE FIRST GRADE OF A PRIMARY SCHOOL)
}

\author{
Sri Supiah Cahyati \\ IKIP Siliwangi \\ srisupiahcahyati02@gmail.com
}

\begin{abstract}
This research entitled: "An Analysis of Using English in Classroom Interactions (A Study at the First Grade of a Primary School)" to investigated the practice of using English in classroom interactions at the school. It is intended: 1) to identify and describe the teachers' and students' perceptions on the use of English in classroom interactions; 2) to identify, describe, and categorize the techniques of teaching English used by the teachers. The study reported here made use of qualitative research design as its method. It revealed that: all teachers and students regarded the practice of using English in classroom interactions as being useful in order to improve students' English ability; in the practice of teaching English, teachers used various techniques and language exposures to students; the students' achievement on the basis of the English syllabus shown that most of the targets in the syllabus were achieved and students could interact with teachers in simple English. However, there were some learning objectives that were not completely achieved, such as writing and reading words in English.
\end{abstract}

Keywords: English, Elementary school

\section{INTRODUCTION}

As a matter of fact, teaching English at elementary school is a new trend, sometimes it is used to attract more students. In this case, Liando suggests that it is needed to consider the implementation of teaching English from the early level of education, i.e. in primary school, in order to attain better results in students' English proficiency in higher levels of education. Teaching English in primary school should be seen as an innovative way in improving teaching English in general (Liando, 2000). However, there are some problems in its implementation. The problems arise when the recruitment of teacher is not adequate in terms of quality. The teacher has a minimum proficiency in teaching English, therefore the lesson is not interesting, students get bored, and finally it becomes far from its aims. Actually, teaching English needs a specific method in each level. In fact, there are the pros and cons to the teaching and learning English at elementary school. It may bring about better results in the long run, but it should be taken into account that the syllabus should be well designed, teaching material well prepared, and teachers well trained. Otherwise, the teaching of English at this level will only defeat its purpose (Alwasilah, 2000; Mustafa, 2008).

This research observed one of private primary school in Cimahi which claiming itself as an alternative education center, promotes advancements to the curriculum development and instructions. In addition to the national curriculum, this school employs its own curriculum in teaching English, which makes English as a compulsory subject for the students from the first grade. In order to develop the students' speaking ability, the teachers teach the subject matters in Indonesian but use English and Indonesian interchangebly in their communication with the 
students, inside and outside classroom. The study reported here is intended to investigated the teaching and learning English at this school. There are some problems related to this investigation:

a. How do teachers, students, and parents at this school perceive the use of English in classroom interaction?

b. How is the practice of using English in classroom interaction conducted by the teachers? Objective of the research are to identify and describe the teachers' and students' perceptions on the use of English in classroom interactions. To identify, describe, and categorize the techniques of teaching English used by the teachers.

\section{METHOD}

This study made use of qualitative research. McMillan (2005) cites some characteristics of qualitative research: it is carried out in natural settings, provides rich narrative descriptions, concerns with process, and perspectives of participants are important. The goal in qualitative research is to understand participants from their point of view. (Cresswell, 2007; Maxwell, 2000). In doing this study, the writer used the observer participant role. The particular role was taken as she primarily observed and took notes in class observation. However if it was needed, there might be a slight change in the role. The role might change to participant observer when she intended to find a more in-depth data from her respondents. Lynch (2010) named these roles as moderate participant, that is "the observer alternating between active and passive roles within the setting" (McMillan, 2005). The transferability of its findings would be limited to those settings that have essential characteristics similar to the context of this study.

Setting of the study was the chosen school because of its educational initiatives in teaching and learning English at elementary school in order to promote English to its students. For example, English and Indonesian are used in all classroom interactions. The teachers teach the subject matters in Indonesian but using English and Indonesian in their communication with the students, inside and outside classroom. It also adopts the government curriculum, which allows the school to have English as an extra curriculum study or local content. The subject of this study are the teachers, students and their parents.

In qualitative research, the researcher is the key instrument. However, in collecting data, the writer has to employ appropriate instruments such as observation checklists, interview, questionnaire, also field notes and audio-recorder. In this study, the writer conducted class observation 16 times. Data gathered from the interviews and observations were all transcribed and analyzed inductively by employing classroom interactions analysis. As McMillan (2005) suggests, qualitative researchers do not formulate hypotheses and gather data to prove or disprove them. Rather, the data are gathered first and then synthesized inductively to generate generalizations. Interview with the teachers indicated that through the practice of using English in classroom interactions the students learned English effectively. The student who was shy or quite, now become more active and cooperative. They can sing some songs in English and they understand simple conversation in English. The more they store vocabulary, the more they understand simple English to express their feeling or opinion.

Based on the class observation it was clear that students learned English enthusiastically, particularly when they learned it through singing, using computer and telling a story. They learned English enthusiastically, particularly when they learned it in a holistic way through singing, using computer, telling a story, etc. In line with this, parents of the students also have the same perception. Based on the questionnaires administered to parents, it can be concluded that all of them support the practice of using English in classroom interactions. They choose 
this school because of the practice of using English and Indonesia in their communication with students, inside or outside the class, the good facilities of teaching and learning, and the like. Interview with the parents revealed that their children practiced some English vocabularies with their brothers, parents or friends, and they enjoy learning English. As a triangulation to validate the data obtained,

Based on the data above, it showed that all teachers, students, and parents regarded the practice of using English in classroom interactions as being useful in order to improve students' English ability. All of them perceived the use of English in classroom interaction is good and they support it. They regarded the practice of using English in classroom interactions as being useful in order to improve students' English ability. Based on the class observation, the teaching and learning activities at this school can be drawn as follows:

1. All the teachers used English in communication with the students, both inside and outside the class, in order to provoke students' English ability. To make it more understandable by students, they used English and Indonesian interchangeably.

2. Teachers introduced some English vocabulary to develop listening and speaking skills, through singing songs and acting out poems. Observation shows that the teachers do such activity everyday during the first term so that students are more familiar with English, particularly for the listening comprehension. This repetition of the same routines make students soon acquire the language involved and can begin to use it themselves to organize activities or games. This is proved by the explanation of parents. They described how their children in the First term acquired some simple English with their brothers/friends.

3. Teachers made use of various exposures and techniques in explaining some topics. Classroom Observation showed how in English lesson teacher explained the names of the animals through colouring the picture of some animals and writing the names and its colour. Then, students one by one was asked to mention the names and the colour of the animals. Thus, they learn writing, naming animals, and colouring at the same time.

4. Brown (2011) suggests that children at the beginning levels have "short attention spans" or immediate interest. This comes up only when a teacher presents the lesson that to them is boring, useless, or too difficult. Therefore, teacher's job is making them interesting, lively, and fun so that students would be involved actively (Paul, 2003). The teachers at this school are aware about this problem, and they use English material as their variety in order to engage students in learning English.

5. The contents of subject matters were discussed in LI (Indonesian) to facilitate students' better understandings. The teachers made use of Indonesian teaching dealing with the content of subject matters. When teachers try to teach new concepts in English to the students who have not already learned the concepts in LI, instruction in the first language can give some benefits to the second one. When students do not have a not sufficient oral ability yet in L2, it is a good idea for the teachers not to teach a new concept in L2 until it has been taught in LI. Once it has been taught in LI, it may be quickly transferred to L2 (Cantony-Harvey, 2002; Nunan, 1995).

6. In reading, the teacher translates sentence by sentence to help students understand the content. Actually this technique makes the students understand the story better.

7. Students had difficulty in learning some abstract concepts. From this point of view, teachers play very important roles because students at this level have little or no prior knowledge of English and their learning success might, to some extent, depend on teachers' creativity. Teaching children a foreign language successfully requires specific skills that differ from that of teaching adults. In this case, when students have difficulties 
in learning the concept of "the Months", it is wise for the teachers to take into account the level of the students' knowledge. This is related to Krashen's theory mentioned before that teacher should ensure a close match between the level of delivery and the understanding level. Since the students had not known this term yet in LI, they found it more difficult in L2.

8. Teachers made use of various exposures and techniques in explaining some topics. As Brown (2011) suggests, a variety of techniques are important because of limited language capacity. Students learned the Shapes, name of the animals by coloring them and writing their names. They developed their vocabulary through Total Physical Response. Then, students learned "Introducing" through Role Playing. Teacher guided students in greeting, and asking and answering questions about name and address. In line with this, Ellis (1988) claims that Asher's Total Physical Response and Terrel's Natural Method are likely to succeed because they can foster the language acquisition.

9. Students had difficulty in writing and reading English words. For the first grade students, they understand some English vocabularies and can write the meaning in Indonesian, but they still have difficulty in writing and reading it in English. They find it difficult to transfer the spoken to the written words. It is because of the differences between the letter and the sound in English. In Indonesian, every single word is pronounced the same as its spelling, while in English is not. Furthermore, according to Krashen and Terrel, a natural approach is required in language teaching. Its main tenets are as follows: comprehension of language should precede production (listening should precede speaking); speaking and then writing will emerge when the language learner is ready and should not be forced (Krashen \& Terrel in Baker, 2000; Ioannou-Georgiou \& Pavlou. 2003). It is wise for the English teachers at Elementary Education to consider this psychological aspect that for the beginner the essential thing is "the association between the sound and the meaning", rather than "the association between the sound and the orthography". This present study revealed some findings about the teachers that not all of the teachers had a good proficiency in teaching English, like fluency and accuracy.

In relation to the teacher's lack of competence, this study recommends that all of the teachers should be more competent in teaching English, particularly in pronunciation. In fact, pronunciation is an important aspect in speaking through which students can imitate their teachers. As we know, students are good imitators. As a good teacher, we have to provide the students with a good basic in their early stage of learning English. Providing a misconception about English, e.g. pronunciation, will make the students grasp something wrongly that they may imitate continuously. In this case, it will be better to "unlearn" than to "undo". It also revealed that indicated that not all of the teachers had teachers training background. Refer to the teachers' educational background as mentioned above, there is a phenomenon that seems to be different from that in common sense: "the teachers of non teacher training background will find themselves difficult in conducting the teaching and learning process".

In addition, they are creative to suit materials of teaching to students' need. For example, to develop listening and speaking skills they use songs and poems (singing and acting-out the poems), and use English as a means of interaction between teachers and students, inside and outside classroom. Then, to develop reading and writing skills, they use storytelling, colouring, and students also learn to write in English through others subjects. To improve vocabulary, they make use of computer. All of these techniques show that the teachers have provided challenging and varied learning activities and experiences to motivate students to attain high levels achievement. 
However, there are some problems in teaching English at Elementary school, such as difficulties in teaching some abstract concepts, the unrealistic target to expect the first grade students to be able to write words in English as expected in syllabus, and the teachers' lack of a good command in English and the basic assumptions of children psychology.

So, in order to achieve a better result in teaching English at Elementary Education, it is better for the teachers at this school to consider Harmer and Musthafa's proposal (Harmer, 2003; Musthafa, 2010). They proposes that there are some major areas of necessity knowledge for the teacher in English teaching: first, the language for the level (the teacher must know and master the language that is to teach their students); second, the skill for the level (the teacher himself needs to know/master the language skills that he is going to perform); third, the aid available for the level (the teacher has to know what aids are available and appropriate for the level of his/her teaching); fourth, stages and techniques in teaching (the teacher needs to know and recognize the different teaching technique and stages); fifth, a repertoire of activity (a well prepared teacher has a large repertoire of activities for his/her class, he/she can direct students in improving product skills and in acquiring receptive skills and organize genuine communicative activity); and last, classroom management skills (he/she will be able to adopt a number of different students grouping and to maintain discipline in the classroom).

It is better for teacher to be aware that students differ in temperament. Some students are aggressive, some are shy, some are over-anxious to please and in some cases frightened of making a mistake, others are moody, especially if they do not get what they want. Temperament affects their ability to take part in language-learning activities. In this case, if the activity is right for the students, they will keep involving and listening to the lesson. Children in the primary level acquire language by taking part in activities, in which they need to communicate. Actually, the need to communicate in English is necessary and the first lesson activities should take place in English (Brewster, Ellis, Grard. 2003; Harmer, 2004). With constant repetition of the same routines, students immediately acquire the language involved and start to use it themselves to organize activities or games.

As Damayanti (2007) mentioned, students come to English lessons with expectations about what they are going to do and to get. These expectations are influenced by what the family, friends and the society expect and what they have heard from other students. The students also want to please, they want to have immediate results. They expect to be able to speak some English after the first lesson so that they awarded by their parents and their friends (Linse, 2005). Actually, teacher should consider that students in the Concrete Operation stage would more understand the explanations if the teacher used realia in teaching some abstract concepts, i.e. the shapes. Facing the student difficulties in learning, teacher were always tried to give more exposures and to create another activity, such as teaching the Shapes through colouring, drawing, arranging the shapes, and grouping the things which are appropriate with their shapes so that the student could understand the concept.

Teachers used English in managing the class. For reinforcement, teacher gave homework to students. As we know, most parents of students are interested in knowing exactly what is going on in the lesson. The teachers generally find that parents appreciate to be informed or invited to informal class functions. So, the "Response Book" is very good in order to achieve the good relationship between teacher and parents, between school and home. 
Regarding to the teachers' English competencies (in teaching) and school facilities, they so far could handle the teaching and learning activities. In addition, they used English in their communication with students. The effort of the teachers in using English in interactions with students is a good way in order to provoke students' speaking ability. However, qualified language teachers are needed to give a good basic to students' English ability, e.g. pronunciation.

Meanwhile, dealing with some learning outcomes or students achievements that had not completely met the target in syllabus, i.e. writing words in English, it is wise for the teachers to consider the students' readiness. And it is unrealistic to expect the first grade students to write in English as expected in syllabus. According to the natural approach, comprehension of language should precede production (listening should precede speaking); speaking and then writing will emerge when the language learner is ready and should not be forced.

So, the main point in teaching English at the first grade of elementary education is the qualified teachers, the students' readiness, and the adequate teaching-learning facilities.

In fact, teaching English needs a specific method in each level. As Brown (2011) says that teaching children a foreign language successfully requires specific skills that differ from that of teaching adults. In this situation, more teachers' efforts are still needed. It is undeniably important that the school should provide opportunities for the teachers to improve their ability in teaching English, for example, by participating in the teachers training conducted by National Education Department so that the necessity knowledge for the teacher in English teaching can be achieved.

In line with the problem of teaching English in elementary school, Alwasilah suggests that we should be realistic to our strength in fulfilling society's need, and do not expect too much that English program at elementary school would soon be perfect. Moreover he suggests that English should be taught by certified elementary English instructors, otherwise, the students become a victim of emotional rather than professional ambitions. The teaching and learning of English in elementary education should seriously consider the nature of learning a foreign language, the instructional system, and the governance system that governs the whole language educational system. In this case, we have to refer to the students' readiness, teachers' competence, and adequate teaching-learning facilities. It is undeniably important that the school should provide opportunities for the teachers to improve their ability in teaching English, for example by participating in the teachers training.

\section{CONCLUSIONS}

a. Teachers and students regard the practice of using English in classroom interactions is good in order to improve students' English ability. They realize the importance of English, i.e. to absorb, adopt, and create a potential opportunities in order to develop qualified human resources whose skills are required, especially in the free trade era a few years to come. Therefore teachers, students, and parents are in full support of this practice. The teachers used English in their interactions with students through all subject matters, inside and outside the class as an effort to develop the practice of it to students. Teachers used English with students for real life communication and they encourage students not to be anxious in language learning. This effort results in the students' ability to understand some conversations in simple English and to write the meaning in Indonesian.

b. In the practice of teaching and learning English conducted by teachers, they use various techniques and language exposures to students. Teachers are aware that children at the beginning level do not have a prior knowledge of English, and their learning success might, to 
some extent, depend on teachers' creativities. In this school, to develop listening and speaking skills, they used songs and poems (singing and acting out the poems), TPR, Role Playing and, used English in communication between teachers and students inside and outside classroom; to develop reading and writing skills, they used storytelling, colouring, and drawing; and to improve vocabulary, they made use of computer. Teachers also made use of various exposures and techniques in explaining some topics, for example, Mathematics, Computer, Art and Sundanese. This may engage the students in learning English. The content of subject matters, however, was discussed in LI (Indonesian) to make the students more understand the contents. In this case, subject matter is learned through the native language as well as through the second language, which may enable the students to become proficient in a second language, and develop their skill and proficiency in their native language.

This study showed that most of the target in the syllabus had been achieved and students could interact with teachers in simple English. However, there were some learning objectives that were not completely met the target in syllabus, such as problem in writing and reading words in English. There is a problem faced by the students in the first grade that it difficult to transfer the spoken to the written word. It is because English words are pronounced differently from Indonesian. In Indonesian, every single word is pronounced the same as its spelling (letter), while in English is not. Nevertheless, the students were able to comprehend some conversation in simple English, and at home they tended to "show off" their English to the parents or friends.

\section{ACKNOWLEDGEMENTS}

The writer would like to thank students, parents and teachers of the subject research for their time, suggestions, insights and many helps for the time where the writer conduct her research. The writer also would like to show gratitude to IKIP Siliwangi especially English Education Program and its faculty members for always sharing their knowledge and experiences.

\section{REFERENCES}

Alwasilah, A. Chaedar. (2000). Politik Bahasa dan Pendidikan. Bandung: PT Rosdakarya. ----------- (2001). Language, Culture, and Education: A Portrait of Contemporary Indonesia. Bandung: CV Andira.

Baker, Colin. (2000). Foundation of Bilingual Education and Bilingualism. Britain: Multilingual Matters Ltd.

Brewster, Jean; Ellis, Gail; Grard, Dennis. (2003).The Primary English Teacher's Guide (New Edition). England: Penguin English.

Brown, H. Douglas. (2011). Teaching by Principles: An Interactive Approach to Language Pedagogy. New Jersey: Prentice Hall Regents.

Cantony-Harvey, Gina. (2002). Content-Area Language Instruction. USA: Addison-Wesley Publishing Co, Inc.

Cresswell, J.W. (2007). Research Design: Qualitative \& Quantitative Approaches. USA: Sage Publications, Inc.

Curtain, H.A. \& Pesola, C.A. (2001). Languages and Children-Making the Match: Foreign Language Instruction in the Elementary School. Massachusetts: Addison - Wesley Publishing Co.

Damayanti, ika lestari. (2007). Menumbuhkan Minat Belajar Bahasa Inggris pada Anak Usia Dini melalui Storytelling. Makalah dipresentasikan dalam acara seminar dan lokakarya English Language Teaching for Young Learners tanggal 24 Februari 2004. Bandung: Balai Bahasa Universitas Pendidikan Indonesia. 
Dulay, H.; Burt, M. \& Krashen, S. (2000). Language Two. New York: Oxford University Press. Ellis, Rod. (1988). Classroom Second Language Development. UK: Prentice Hall International (UK) Ltd.

Fadilah, Rahmi. (2017). Madeline Hunter's Lesson Plan as Alternative Model for TEYL. Proceedings in English Conference at STKIP Pasundan.

Fisher, J.C. \& Terry, A.A. (1999). Children's Language and the Language Art. USA: McGrawHill.

Hamied, Fuad Abdul. (2000a). Pendidikan bahasa Inggris: 'Conditio Sine Qua Non' untuk Menyiasati Arus Persaingan Global. Pidato pengukuhan jabatan Guru Besar Tetap dalam Pendidikan Bahasa Inggris pada FPBS UPI. Bandung: Universitas Pendidikan Indonesia.

Hamied, Fuad Abdul. (2000b). TEFL - Related Policy Issues in Indonesia. Paper in TEFLIN the $48^{\text {th }}$ International Conference, The Collection of Papers on Reading - Writing and Learner's Autonomy. Jakarta: TEFLIN the $48^{\text {th }}$ International Conference.

Harmer, Jeremy. (2003). The Practice of English Language Teaching. England: Longman Press.

Harmer, Jeremy. (2004). How to Teach English: An Introduction to the Practice of English Language Teaching. England: Longman.

Ioannou-Georgiou, Sophie \& Pavlou, Pavlos. (2003). Assessing Young Learners. Oxford: Oxford University Press.

Krashen, Stephen D. \& Terel, Tracy D. (2001). The Natural Approach: Language Acquisition in the Classroom. UK: Prentice Hall International Ltd.

Liando, Nihta V.F. (2000). Some Perspectives in Improving English as a Foreign Language Program in Indonesian School. Paper in TEFLIN the $48^{\text {th }}$ International Conference, The Collection of Papers on Reading - Writing and Learner's Autonomy. Jakarta: TEFLIN the $48^{\text {th }}$ International Conference.

Lynch, Brian K. (2010). Language Program Evaluation: Theory and Practice. New York: Cambridge University Press.

Maxwell, J.A. (2000). Qualitative Research Design: an Interactive Approach. USA: Sage Publications, Inc.

McMillan, J.H. (2005). Educational Research: Fundamentals for the Consumer. New York: Harper Collins Publishers, Inc.

Mooney, Carol Garhart. (2001). Theories of Childhood: An Introduction to Dewey, Montessori, Erikson, Piaget, and Vygotsky. USA: Redleaf Press.

Musthafa, Bachrudin. (2008). Teaching English to Young Learners: Principles \& Techniques. Bandung: Pasca Sarjana Universitas Pendidikan Indonesia.

Musthafa, Bachrudin. (2010). Teaching English to Young Learners: In Indonesia Context. Jurnal Educationist Vol.IV No.2 Juli 2010.

Linse, Caroline T. (2005). Practical English Language Teaching: Young Learners. New York: McGraw-Hill.

Nunan, David. (1995). Designing Tasks for the Communicative Classroom. New York \& Australia: Press Syndicate of the University of Cambridge.

Paul, David. (2003). Teaching English to Children in Asia. Hongkong; Longman Asia ELT.

Pinter, Annamaria. (2009). Teaching Young Language Learners. Oxford: Oxford University Press.

Richards, J.C. \& Rodgers, T.S. (1986). Approaches and Methods in Language Teaching. USA: Cambridge University Press.

Slattery, Mary \& Willis, Jane. (2005). English for Primary Teachers: A Handbook of Activities and Classroom Language. Oxford: Oxford University Press.

Woolfolk, Anita E. (1995). Educational Psychology (6 ${ }^{\text {th }}$ Edition). Boston: Allyn and Bacon.

26 | An Analysis Of Using English In Classroom Interaction (A Study At The First Grade Of A Primary School) 